\title{
A comparison of interpolation methods on the basis of data obtained from a bathymetric survey of Lake Vrana, Croatia
}

\author{
A. Šiljeg, S. Lozić, and S. Šiljeg \\ University of Zadar, Geography Department, Trg kneza Višeslava 9, 2300 Zadar, Croatia \\ Correspondence to: A. Šiljeg (asiljeg@unizd.hr)
}

Received: 11 November 2014 - Published in Hydrol. Earth Syst. Sci. Discuss.: 23 December 2014

Revised: 29 June 2015 - Accepted: 27 July 2015 - Published: 24 August 2015

\begin{abstract}
The bathymetric survey of Lake Vrana included a wide range of activities that were performed in several different stages, in accordance with the standards set by the International Hydrographic Organization. The survey was conducted using an integrated measuring system which consisted of three main parts: a single-beam sonar HydroStar 4300 and GPS devices; a Ashtech ProMark 500 base, and a Thales Z-Max ${ }^{\circledR}$ rover. A total of 12851 points were gathered.

In order to find continuous surfaces necessary for analysing the morphology of the bed of Lake Vrana, it was necessary to approximate values in certain areas that were not directly measured, by using an appropriate interpolation method. The main aims of this research were as follows: (a) to compare the efficiency of 14 different interpolation methods and discover the most appropriate interpolators for the development of a raster model; (b) to calculate the surface area and volume of Lake Vrana, and (c) to compare the differences in calculations between separate raster models. The best deterministic method of interpolation was multiquadric RBF (radio basis function), and the best geostatistical method was ordinary cokriging. The root mean square error in both methods measured less than $0.3 \mathrm{~m}$.

The quality of the interpolation methods was analysed in two phases. The first phase used only points gathered by bathymetric measurement, while the second phase also included points gathered by photogrammetric restitution.

The first bathymetric map of Lake Vrana in Croatia was produced, as well as scenarios of minimum and maximum water levels. The calculation also included the percentage of flooded areas and cadastre plots in the case of a $2 \mathrm{~m}$ increase in the water level. The research presented new scientific and methodological data related to the bathymetric features, surface area and volume of Lake Vrana.
\end{abstract}

\section{Introduction}

Bathymetric surveying has undergone many conceptual changes in the last few decades, especially since the mid 20th century due to the availability of the single-beam echo sounder. Rapid advances continued with the development of multi-beam sounders and laser systems (airborne laser sounding systems) which can gather high-density data samples and enable the development of a realistic underwater bottom model (Finkl et al., 2004; Ernstsen et al., 2006).

The process of hydrographic measurement includes measurement and establishing the configuration of the bottom of an ocean, sea, river, lake or any other water-related object on Earth (NOAA, 1976). The main goal of most such hydrographic surveys is to gain data necessary to develop nautical charts featuring special details of types of navigational hazards. Other goals include gaining information crucial to the management and protection of coastal areas, exploitation of resources, national spatial data infrastructure and tourism purposes. (IHO, 2005). Contemporary bathymetry, as a field within hydrography, is the science of measuring depths and determining the physical properties of the underwater features on the basis of analysing data gained from recorded profiles. There are several different methods and techniques for bathymetric measurement, which depend on the complexity of the project. The success of bathymetric measurement depends mostly on a detailed planning process, which in turn enables the organization and tracking of the measurement process from start to finish (IHO, 2005). During this particular research, the measurement plan included a wide range of activities and was performed in several phases according to the standards of the International Hydrographic Organization. The area surveyed included the whole of Lake Vrana, 
with a total surface area of $29.865 \mathrm{~km}^{2}$ (Šiljeg, 2013). Lake Vrana is the largest, natural, freshwater lake in the Republic of Croatia. This cryptodepression is an ecologically sensitive area, located in the Mediterranean part of Croatia (Zadar County) (Romić et al., 2003). The lake is an important economic resource for the local community, but also provides a natural habitat for many bird species (Šikić et al., 2013). Lake Vrana is a complex body, which also affected the bathymetric survey.

Because the Earth's landforms can be extremely complex, most scientists opt for research via the development and analysis of digital elevation models (DEM) (Dikau et al., 1995; Bishop and Shroder, 2000; Millaresis and Argialas, 2000; Wilson and Gallant, 2000; Tucker et al., 2001; Shary et al., 2002; Chaplot et al., 2006; Wilson, 2011). Most gathered data in elevation sets are point-related, regardless of rapid developments in technology (Wilson and Gallant, 2000; Li et al., 2005; Fisher and Tate, 2006; Wilson, 2011). In order to find continuous surfaces, which are necessary for the process of understanding our environment, some values need to be approximated for areas which are not measured directly. This is done using various methods of interpolation (Collins and Bolstad, 1996; Hartkamp et al., 1999; Hu et al., 2004; Naoum and Tsanis, 2004; Li and Heap, 2008; Erdogan, 2009). The final result of the interpolation is the model that approximates or simplifies the Earth's surface. Each method produces a different result, so the main challenge is to determine the characteristics of errors and variability of approximated values by comparing and testing different interpolation methods.

The bathymetric survey of Lake Vrana was performed in order to enable optimal management of the water level, to classify the lake's bottom, to create a model and bathymetric map, and to enable better management and protection of the lake's flora and fauna. This process includes all the hydrotechnical measures which can determine changes of the timeand-space distribution of affected water, enabling a more efficient management of natural water resources. The water regime includes the entire dynamics of constant change: quantitative and qualitative water characteristics and the dynamics of the interchange between water and the environment (Ožanić, 2002; Kuspilić, 2008). A lack of systematic water regime management has led to extreme fluctuations in the water level, salinity, temperature and oxygen levels. This has resulted in lakes being under-exploited and underprotected in many ways, for example in terms of tourism, water resource use, biodiversity and ecology. The unsatisfactory protection culminated in a series of negative consequences in 2012, when a record number of fish died (Večernji list, 2012).

An optimal water regime can only be achieved if the amount of water in the lake is known at any moment, and if Prosika drainage canal has a regulatory water infrastructure, as well as an efficient drainage ditch used to regulate the water level, depending on the season. The canal (dimensions: $875 \mathrm{~m}$ length, $8 \mathrm{~m}$ width and $4-5 \mathrm{~m}$ depth) which connects Lake Vrana and the Adriatic Sea was dug through in 1770 to

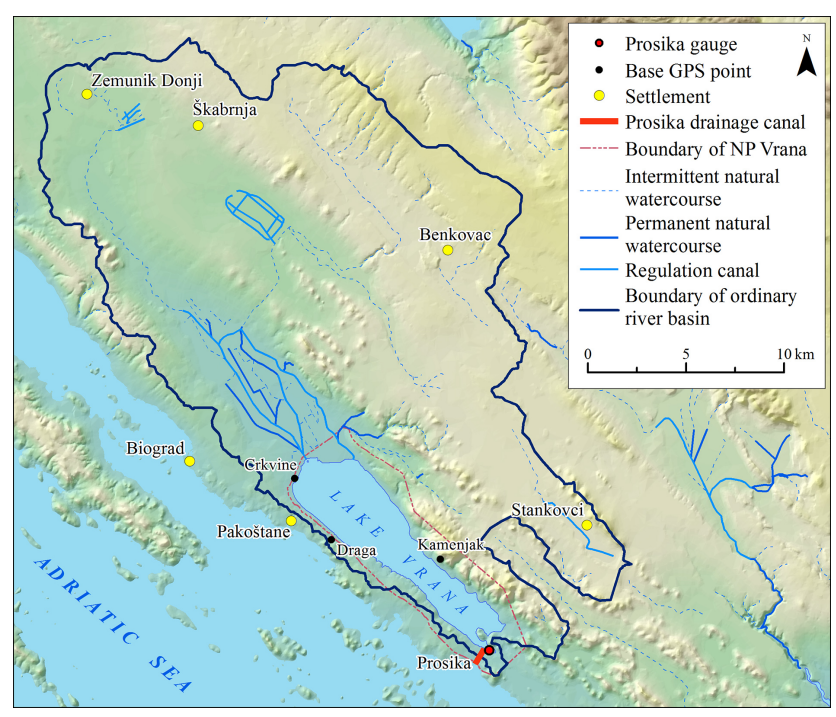

Figure 1. Study area with ordinary river basin.

attain new agricultural areas in Vrana fields and protect them from seasonal flooding.

The main aims of this research are as follows: (1) to compare the efficiency of 14 methods of interpolation and determine the most appropriate interpolators for the development of a raster model of the lake (on the basis of data gained by bathymetry and by using the cross-validation method); (2) to calculate the surface area and volume of the lake and to compare the results between the raster models; (3) to develop the first bathymetric map of Lake Vrana which will enable calculation of the percentage of flooded areas in the Lake Vrana Nature Park and the flooded plots, in the case of a $2 \mathrm{~m}$ rise in the water level. This will serve as tool for developing a scenario for future changes in water level.

\section{Study area}

Lake Vrana in Dalmatia is the largest natural lake in Croatia, with a surface area of $30.2 \mathrm{~km}^{2}$, a length of $13.6 \mathrm{~km}$ and a width of 1.4-3.5 km (JUPPV, 2010).

The surface area of the lake changes frequently. During the period from 1948 to 2008, the lowest water level was $15 \mathrm{~cm}$ (measured in reference to the Prosika gauge) or $0.03 \mathrm{~m}$ above sea level, measured in 1990 and 2008. Prosika gauge is located in the north part of the Prosika drainage canal (Fig. 1). The highest water level was $236 \mathrm{~cm}$, measured with reference to the Prosika gauge $(2.24 \mathrm{~m}$ a.s.l. measured in 1974 and 1994). The mean value was $0.81 \mathrm{~m}$ a.s.l. (JUPPVJ, 2010). The water level is influenced by factors such as inflow, drainage and evaporation, but also by complex hydrological and hydraulic effects such as water balance, salt and fresh water content, sea tides and other factors influencing changes in sea level (JUPPVJ, 2010). 
The characteristics of Lake Vrana water system affected the selection of methods for the bathymetric survey. The area included Lake Vrana in its entirety, with a surface area of $29.865 \mathrm{~km}^{2}$ (in relation to the water level of $+0.42 \mathrm{~m}$, measured in reference to the Prosika gauge) (Šiljeg, 2013).

The lake is characterized by following characteristics:

1. A high percentage of shallow water - over $65 \%$ of the lake's surface - features a water depth of $-1.76 \mathrm{~m}$, while the deepest is $-3.73 \mathrm{~m}$ (in relation to the water level of $+0.42 \mathrm{~m}$, measured with reference to the Prosika gauge or $0.3 \mathrm{~m}$ a.s.1.).

2. Low vertical dissection - the absolute vertical difference over the entire area of the lake bottom - is only $3.46 \mathrm{~m}$. More than $90 \%$ of the lake's bottom features a slope inclination of $2^{\circ}$.

3. Low water transparency and high turbidity, especially during even the slightest winds.

4. Lush vegetation (grass) on the lake's bottom and the surrounding shoreline (Phragmitetalia).

5. Significant seasonal oscillations in the lake's water level.

6. Coverage of parts of the lake's bottom by unconsolidate sediments.

\section{Research materials and methods}

\subsection{Equipment used}

Based on the characteristics of the lake, more efficient techniques, such as measuring using a multi-beam echo sonar, or laser sonar, would have been inappropriate, considering the morphology of the bottom. The percentage of the recorded bottom would increase greatly in relation to recordings from a single-beam sonar, but the cost of the survey and amount of data acquired would significantly increase as well. After consideration, it was clear that the most efficient solution was bathymetric measurement and the use of a single-beam ultrasound device.

In order to avoid frontal waves (proposed by IHO, 2005), an inflatable Hondawave boat was used (Fig. 2a). The boat was the optimal vehicle due to its small dimensions $(3.85 \mathrm{~m})$ and economical engine, and because it was easy to install the surveying equipment on it.

The bathymetric measurement was performed using an integrated measuring system (Fig. 3) Installed equipment included three main components: a HydroStar 4300 sonar, GPS devices Ashtech ProMark 500 and a Thales Z-Max ${ }^{\circledR}$. These were connected via the Real-Time Kinematic (RTK) controller Juniper System-Allegro, which enabled real-time connection and data registration in the FAST Survey programme.
This enabled recording of the sonar coordinates and corresponding depth. The programme automatically recalculated the coordinates from the GPS into the local projection coordinates. The selected projection was the universal transverse Mercator, Gauss-Krüger shape with a central meridian of 15, a factor of scale change of 0.9999 and a false easting of 5500000 . The Bessel 1841 ellipsoid was used.

Two GPS devices were also used: a base or referential device (Fig. 2b), which was positioned according to precisely determined coordinates, and a rover device (Fig. 2c), which was used in the work area. A data-exchanging connection was established between them via a UHF radio transmitter, which would also have been possible via various GSM devices.

The distance between the base and referential devices had to be determined in advance, in order to achieve an adequate degree of precision. This was named the base line and its maximum value was $50 \mathrm{~km}$. The distance between the base GPS and the UHF transmitter had to be a minimum of $10 \mathrm{~m}$.

Since the UHF signal was rather weak throughout the lake, three base points were determined using the Ashtech ProMark 500 and CROPOS system: (1) coordinates $\lambda=5541365.709, \varphi=4865017.188 \mathrm{~m}-2.02 \mathrm{~m}$ a.s.l. in the northeast section of the Nature Park (Crkvine), (2) coordinates $\lambda=5543$ 197.353, $\varphi=4861981.863 \mathrm{~m}-$ $36.69 \mathrm{~m}$ a.s.l. in the western parts of the Nature Park (Draga), (3) coordinates $\lambda=5548694.214, \varphi=4860958.663 \mathrm{~m}-$ $62 \mathrm{~m}$ a.s.1. in the eastern part of the Nature Park (Kamenjak) (Fig. 1). They were connected by a benchmark and measuring gauge at the Prosika location. A base GPS device was set at those points, depending on the phase of the survey, and connected to a UHF transmitter (with all components) in order to achieve a connection (signal) with the mobile GPS installed on the inflatable boat.

A dual-frequency probe was fixed to this support with a rover GPS device submerged $20 \mathrm{~cm}$ below the water level (Fig. 2c). This arrangement was necessary due to the shallow water of the lake and low water level at the northwest end. Since the HydroStar 4300 sonar supports depth recording simultaneously at two frequencies, the survey was conducted at two frequencies: low $-30 \mathrm{kHz}$ and high $-200 \mathrm{kHz}$.

The bathymetric survey was performed according to the previously established profiles, on a geo-referential cartographic surface (digital orthophoto (DGU, 2012a) and Croatian base map (DGU, 2012b) to the scale 1:5000). The basic measuring profiles were planned perpendicular to the slope of the terrain, in a northeast-southwest direction. The planned profiles of the survey (basic bathymetric profiles) ensured good coverage and high resolution in the research area. The survey also included four transversal profiles which intersected with the main profiles, enabling the comparison and control of the measured depths.

Within the borders of the shoreline of Lake Vrana, 375 basic profiles were achieved. The distance between adjacent 


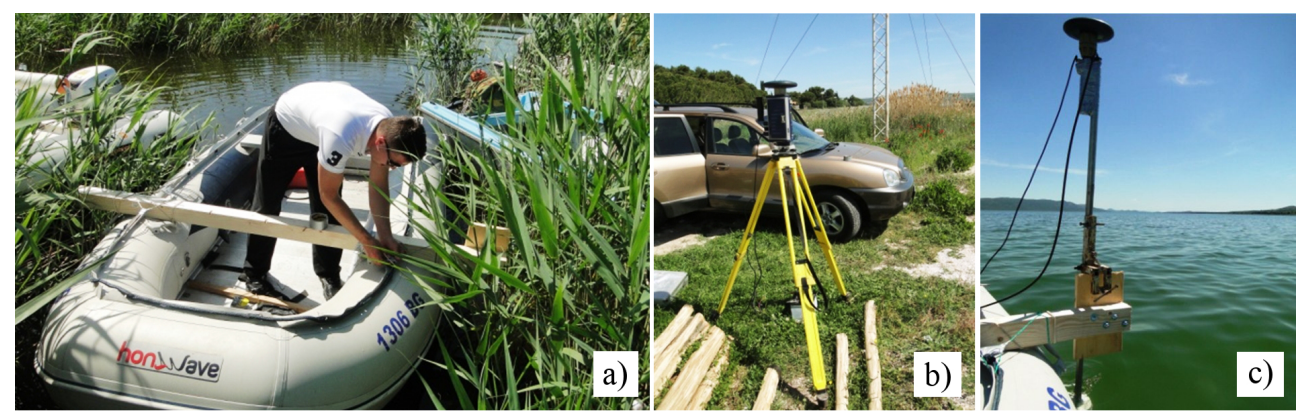

Figure 2. (a) Hondawave inflatable boat with wooden support. (b) Base GPS and UHF antenna. (c) Rover GPS and dual-frequency probe.

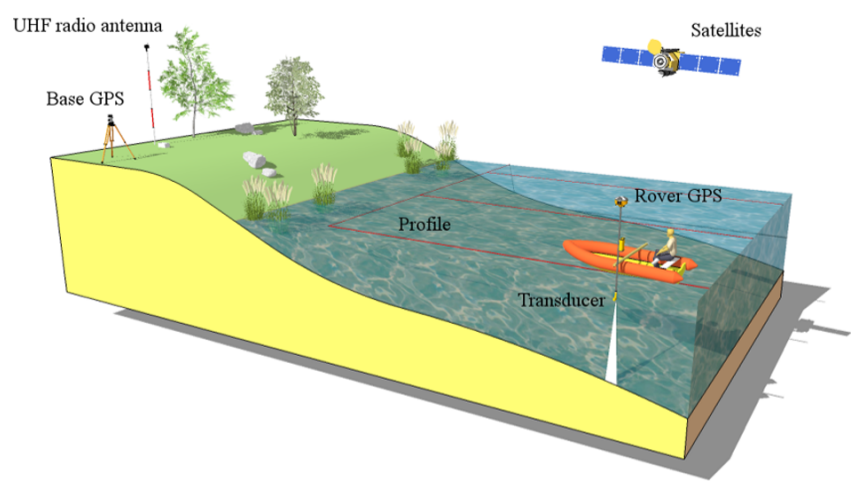

Figure 3. Integrated measuring system - combination of GPS-RTK and a sonar.

profiles was set at $200 \mathrm{~m}$, which corresponds to the desired mapping resolution to the scale 1:30 000 .

\subsection{Time frame}

The time frame, and the first day of the survey were determined by the water level. The water level is important since is it impossible to register a depth of more than $0.5 \mathrm{~m}$ by the transducer. Weather conditions are important for navigation and the quality of data registration (Fig. 4). Wind, rain, waves and cold, for example, are usually limiting factors. Weather reports and water level oscillations were continuously observed from the production of preliminary plans in November 2010 until the beginning of the survey.

The measurement process was conducted in two phases (Fig. 5): (1) from 10 to 12 May 2012, and (2) from 7 to 9 June 2012.

The first phase took 2 days, and included a survey of $14.351 \mathrm{~km}^{2}$ of the northern part of Lake Vrana. The total length of the measured profiles was $71.3 \mathrm{~km}$, and the total amount of points gathered was 5643. In the first phase of investigation the water level measured at the Prosika station was $0.42 \mathrm{~m}$. The limiting factors for the survey in this part of the lake were the dense grassy vegetation on the bottom, the shallow water and the lush surface-level vegetation which hindered navigation. Measurement was cancelled in
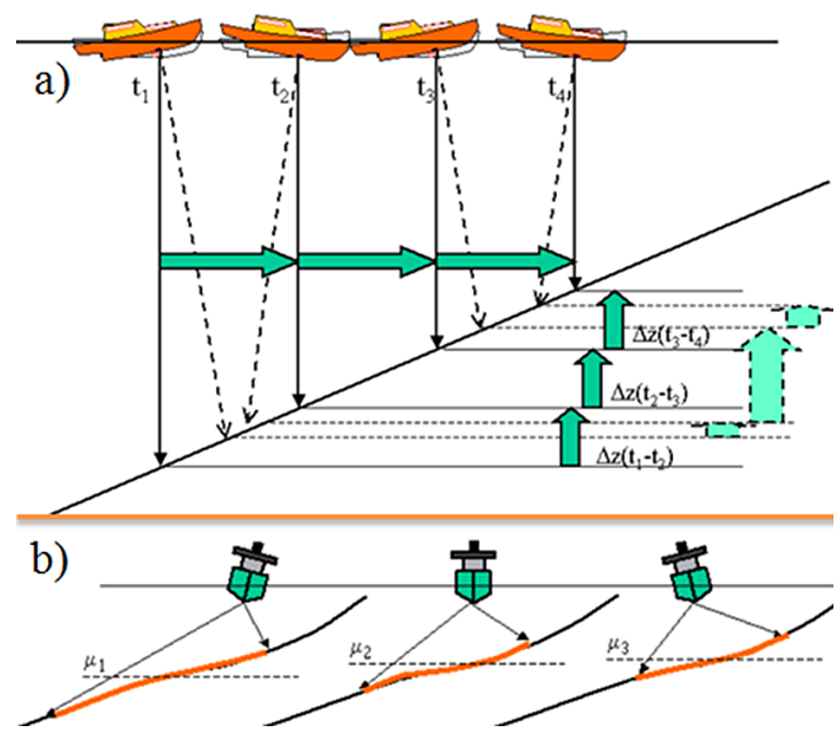

Figure 4. The effect of frontal (a) and dorsal (b) waves on data registration (Clarke, 2003).

these parts, based on previously established profiles, while the shallow water was measured using a plumb line. As a result, this survey cannot be classified as systematic. It is nevertheless very important in relation to the part of the lake that was measured, since the terrain there is flat or minimally inclined. An acceptable level of interpolation is possible in areas featuring an irregular layout of profiles. The second phase featured negligible limiting factors, so the survey was conducted according to plan. The water level at the Prosika station was $0.37 \mathrm{~m}$. A total area of $15.514 \mathrm{~km}^{2}$ was surveyed in the southern part of the lake. The total length of the measured profiles was $82.5 \mathrm{~km}$, and the total amount of points gathered was 7208 .

\subsection{Processing the Bathymetric data}

The data obtained from measurement were transferred to a PC via the Juniper System-Allegro controller and the FAST Survey programme package for further processing and interpolation. During measurement, the controller creates a sep- 


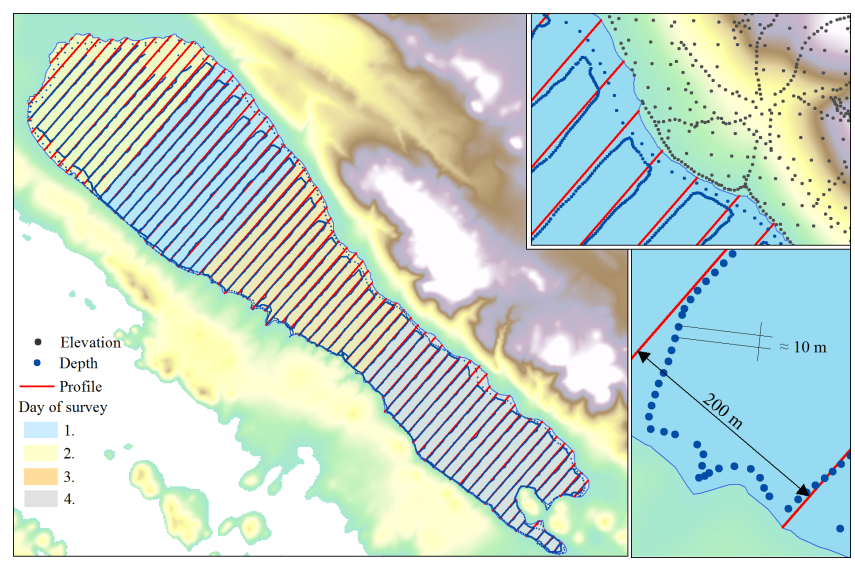

Figure 5. The phases and plan of the bathymetric survey.

arate file with information regarding the point coordinates, time obtained, and depth recorded. Data processing included filtering out noise, calibrating the checked depths to a common referential level and interpolation. The filtering process was implemented according to a programme which enabled the removal of errors in the data registry (Fabulić, 2012). Records of water depth were calibrated in relation to the Prosika benchmark and measuring gauge.

Since parts of Lake Vrana are quite difficult to survey, measurements taken by ultrasound showed some background noise. In simple terms, the ultrasound beam bounces off the first obstacle it encounters, so the echo sounder calculates the distance to that obstacle and represents it as a depth measurement. However, such obstacles are not always at the bottom of the lake, and indeed, random noise may be generated by floating matter, plankton, fish, or vegetation (Pribičević et al., 2007). These sounds need to be filtered and reduced in order to obtain correct, usable data. An additional caution is necessary when filtering such data. Low frequencies $(30 \mathrm{kHz})$ cannot penetrate the dense, complex, "sedimentary" vegetation which forms the new bottom. As a result, the low-frequency measurement did not yield adequate results, since it could not properly determine the density of the silt or vegetation, or the boundary between the rocky and muddy bottom. Therefore it was used only during the first day of the survey. Another deficiency recorded using low frequency was significant leaps in profiles, especially in places where the frequency penetrated the vegetation and muddy deposits. This also indicated significant differences in the levels of muddy deposits. In order to perform a more detailed analysis, a sediment profiler should be used, featuring a frequency of up to $15 \mathrm{kHz}$, which could be used to gain detailed information regarding the lake's bottom (Lafferty et al., 2005; Pribičević et al., 2007). Since the lake is shallow, and water transparency during the survey was relatively good, it was relatively easy to determine the features of the lake's bottom and differentiate vegetated from non-vegetated areas.

\subsection{Interpolation methods}

The spatial interpolation methods have been applied to many disciplines, where the most prominent are from the environmental sciences (Burrough and McDonnell, 1998; Webster and Oliver, 2001; Zhou et al., 2007). In comprehensive published studies, many authors (Aguilar et al., 2005; Weng, 2006; Zhou et al., 2007; Li and Heap, 2008; Heritage et al., 2009; Guarneri and Weih Jr., 2012; Tan and Xiao, 2014) compared the performance of the spatial interpolation methods. Some studies indicate that among the many existing interpolation techniques, geostatistical ones perform better than the others and vice versa ( $\mathrm{Li}$ and Heap, 2008). Although there have been many studies on the accuracy of interpolation techniques for the generation of digital elevation models (DEMs) there is still a need to evaluate the performance of these techniques (Chaplot et al., 2006) because there are still no consistent findings about the performances of the spatial interpolators ( $\mathrm{Li}$ and Heap, 2008; Tan and Xiao, 2014). In this paper we compared the 14 interpolation methods implemented in the Geostatistical Analyst extension (ESRI, 2013).

The most appropriate methods have been chosen, based on seven statistical parameters: minimum value, maximum value, range, sum value, mean value, variance and standard deviation. Of these, standard deviation, or root mean square error, is especially worth mentioning, since it is the most used method worldwide for determining the precision of digital elevation models (Yang and Hodler, 2000; Aguilar et al., 2005). In addition to analysing parameters, interpolation methods were compared on the basis of high-fidelity, two-dimensional and three-dimensional graphic representations of data sets. Volume comparison methods were also used, by employing various algorithms, as well as methods for calculating and comparing profiles (Pribičević et al., 2007; Medved et al., 2010).

In order to compare the accuracy of the interpolation methods, the method of cross-validation was used. Most authors suggest using this method in order to achieve a successful evaluation of accuracy (Cressie, 1993; Smith et al., 2003; Webster and Oliver, 2007; Hofierka et al., 2007).

The 14 interpolation methods were used as follows (with abbreviations):

Deterministic methods: inverse distance weighting (IDW), local polynomial function (LP),

RBF (radial basis function) - completely regularized spline (CRS), RBF - spline with tension (SWT), RBF multiquadric function (MQ) and RBF - inverse multiquadric (IMQ).

Geostatistical methods: ordinary kriging (OK), simple kriging (SK), universal kriging (UK), disjunctive kriging (DK), ordinary cokriging (OCK), simple cokriging (SCK), universal cokriging (UCK) and disjunctive cokriging (DCK). 


\section{Research results}

\subsection{Interpolation of data gathered from the bathymetric survey}

In order to generate continuous areas necessary for research and knowledge of the bottom of Lake Vrana, it was necessary to approximate values in areas that were not sampled directly. This was done using various interpolation methods. The effectiveness (quality) of interpolation methods was analysed in two phases. In the first phase, 12851 points were used to develop a model of the lake and compare interpolation methods. The second phase covered 30233 points. Using the ArcGIS extension within the Geostatistical Analyst programme, interpolation parameters were automatically optimized for each interpolation method (Table 1).

Four parameters influenced the quality of the output deterministic methods results: distance exponent, number of neighbours, distance and number of sectors. The number of neighbours which influenced an approximated point was set at 15 . The criteria for distance used a circular search zone with a defined distance radius. All methods, except local polynomial methods, featured a radius of $3619.9 \mathrm{~m}$ (Table 1).

Geostatistical methods are more demanding to process, since they require semi-variogram modelling and the appertaining defining parameters.

The first phase showed that all methods of interpolation showed satisfying results based on the ranges of values of the standard deviation $(0.058 \mathrm{~m})$, and were adequate for developing digital elevation models of the lake, since they had similar parameter values (Table 2). The main reason for this is the slight difference in depth values, low vertical dissection of the lake's bottom and minimal percentage of elements with sudden leaps in height. The range of value for standard deviation, considering the automatically optimized parameters, was between 0.197 and $0.255 \mathrm{~m}$. According to all parameters, the best method was simple cokriging $(0.197 \mathrm{~m})$. The reasons for that were the principle of the method's process $(\mu=$ known stationary mean value, taken as a constant for the entire research area and calculated from the median data value) and the maximum range between the depth values (only $-3.46 \mathrm{~m}$ ). The mean value for the entire area was $-1.763 \mathrm{~m}$.

Since most authors point out that the quality of stochastic methods depends on the choice of criteria regarding semivariograms, a comparison was made between the criteria automatically determined by software and those manually determined for the ordinary cokriging method. The two most common theoretical models were tested: spherical and Gauss (Table 3). The purpose of manually assigning criteria is to find out the minimum deviation and minimum value for standard deviation. In the case of the spherical model, the minimum value of standard deviation was the distance of $1800 \mathrm{~m}$ $(0.221 \mathrm{~m})$. Unlike the automated software process, finding the minimum value of standard deviation manually is more

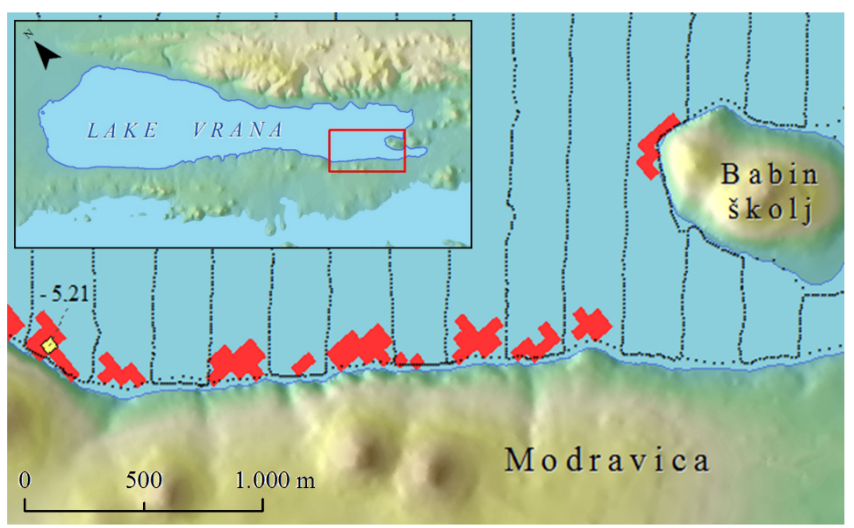

Figure 6. Areas that were not directly measured during the survey (red squares).

difficult and time-consuming (it requires inputting the parameters of interpolation repeatedly until the minimum value is found).

Table 3 shows that the output results regarding the standard deviation do not reveal significant differences. For example, the difference between automatic and manually found standard deviation in the case of the spherical model for 12851 points is $0.011 \mathrm{~m}$. However, it is notable that the maximum error in the approximation for the same model is $0.208 \mathrm{~m}$ greater $(2.238 \mathrm{~m})$.

According to Malvić (2008), a decrease in distance also decreases the deviation, since the values of closer points are more similar than the values of more distant ones. The decrease in deviation should decrease the standard deviation calculated from the differences in the measured and the approximated values. However, the quality of approximation in other parts of the model might be questioned. By testing using ordinary kriging, the conclusion was that the decrease in distance affected the standard deviation positively, and negatively in areas that were not included in the direct measurement. The values obtained in such areas greatly surpassed the values of the surrounding measured points. For example, a semi-variogram for Lake Vrana was made, which was used to compare 30233 points. The determined distance was $1200 \mathrm{~m}$, and the standard deviation for 12851 points was $0.298 \mathrm{~m}$. For the distance of $12000 \mathrm{~m}$, the standard deviation was $0.471 \mathrm{~m}$. In the case of the first distance $(1200 \mathrm{~m})$ the lowest value of depth for the entire model was $-5.21 \mathrm{~m}$ (the lowest measured depth was $-3.73 \mathrm{~m}$ ). As much as $0.246 \mathrm{~km}^{2}$ of the model's surface fell within the category of -3.73 to $-5.21 \mathrm{~m}$ (Fig. 6). This result implies a serious error that would create an increase in the volume of the lake. The second distance $(12000 \mathrm{~m})$ did not feature any values above $-3.578 \mathrm{~m}$. This example shows that standard deviation can be an unreliable parameter when taking the values of the entire model into account. 
Table 1. Parameters of interpolation methods calculated only on point data gathered by bathymetric measurement.

\begin{tabular}{|c|c|c|c|c|c|c|c|c|c|}
\hline $\mathrm{IM}^{*}$ & Power & Model & Range & Sill & Nugget & Lag & Distance & $\mathrm{NL}^{*}$ & $\mathrm{NS}^{*}$ \\
\hline IDW & 2 & & & & & & 3619.90 & & 1 \\
\hline LP & 1 & & & & & & 228.20 & & 1 \\
\hline CRS & 12.3 & & & & & & 3619.90 & & 1 \\
\hline SWT & 17.7 & & & & & & 3619.9 & & 1 \\
\hline MQ & 0 & & & & & & 3619.90 & & 1 \\
\hline IMQ & 0 & & & & & & 3619.90 & & 1 \\
\hline $\mathrm{OK}$ & & Spherical & 8496.40 & 0.591 & 0.227 & 886.11 & 10633.32 & 12 & 4 \\
\hline SK & & Spherical & 2453.10 & 0.496 & 0.088 & 394.96 & 4739.52 & 12 & 4 \\
\hline UK & & Spherical & 10058.80 & 0.000 & 0.031 & 886.11 & 10633.32 & 12 & 4 \\
\hline DK & & Spherical & 2395.60 & 0.767 & 0.223 & 388.72 & 4664.64 & 12 & 4 \\
\hline OCK & & Spherical & 6461.03 & 0.560 & 0.191 & 886.11 & 10633.32 & 12 & 4 \\
\hline SCK & & Spherical & 2451.89 & 0.496 & 0.087 & 394.88 & 4738.56 & 12 & 4 \\
\hline UCK & & Spherical & 8496.35 & 0.000 & 0.030 & 886.11 & 10633.32 & 12 & 4 \\
\hline DCK & & Spherical & 2394.07 & 0.768 & 0.221 & 388.57 & 4662.84 & 12 & 4 \\
\hline
\end{tabular}

* IM - interpolation method, NL - number of lags, NS - number of sectors.

Table 2. Cross-validation results calculated only on point data gathered by bathymetric measurement.

\begin{tabular}{lrrrrrrrr}
\hline IM & $\begin{array}{r}\text { Number of points } \\
\text { measured }\end{array}$ & $\begin{array}{r}\text { Minimum value } \\
(\mathrm{m})\end{array}$ & $\begin{array}{r}\text { Maximum value } \\
(\mathrm{m})\end{array}$ & $\begin{array}{r}\text { Range } \\
(\mathrm{m})\end{array}$ & $\begin{array}{r}\text { Value sum } \\
(\mathrm{m})\end{array}$ & $\begin{array}{r}\text { Mean value } \\
(\mathrm{m})\end{array}$ & $\begin{array}{r}\text { Variance } \\
\left(\mathrm{m}^{2}\right)\end{array}$ & $\begin{array}{r}\text { Standard deviation } \\
(\mathrm{m})\end{array}$ \\
\hline IDW & 12851 & -1.748 & 2.265 & 4.013 & -67.424 & -0.005 & 0.062 & 0.249 \\
LP & 12851 & -1.702 & 2.100 & 3.802 & 79.836 & 0.006 & 0.049 & 0.222 \\
CRS & 12851 & -1.702 & 2.239 & 3.941 & -48.410 & -0.004 & 0.052 & 0.229 \\
SWT & 12851 & -1.707 & 2.234 & 3.941 & -49.528 & -0.004 & 0.052 & 0.228 \\
MQ & 12851 & -1.736 & 2.273 & 4.009 & -23.102 & -0.002 & 0.065 & 0.255 \\
IMQ & 12851 & -1.743 & 2.159 & 3.902 & -68.307 & -0.005 & 0.055 & 0.234 \\
OK & 12851 & -1.737 & 2.030 & 3.767 & 19.950 & 0.002 & 0.054 & 0.232 \\
SK & 12851 & -1.701 & 2.177 & 3.877 & -8.482 & -0.001 & 0.050 & 0.223 \\
UK & 12851 & -1.827 & 1.948 & 3.775 & 51.824 & 0.004 & 0.057 & 0.239 \\
DK & 12851 & -1.664 & 2.143 & 3.807 & -3.060 & 0.000 & 0.051 & 0.225 \\
OCK & 12851 & -1.660 & 2.060 & 3.720 & 11.443 & 0.000 & 0.051 & 0.226 \\
SCK & 12851 & -1.526 & 2.007 & 3.533 & -6.873 & -0.000 & 0.038 & 0.197 \\
UCK & 12851 & -1.827 & 1.949 & 3.776 & 51.825 & 0.004 & 0.057 & 0.239 \\
DCK & 12851 & -1.535 & 2.022 & 3.557 & -6.678 & -0.000 & 0.041 & 0.203 \\
\hline
\end{tabular}

Points gathered by the bathymetric survey did not include the entire surface of the lake, since the echo sounder could not gather data in areas above $-0.5 \mathrm{~m}$. Since that resulted in a lack of data at the edges of the lake, the modelling toolset poorly extrapolated the surfaces (Fig. 6).

Compared visually, the methods generally show the greatest differences in the smoothness of isobaths, which is logical since the differences between the chosen parameters are essentially negligible. A more detailed analysis indicates the results of certain methods (appearance of continuous surfaces at micro levels).

In order to develop a digital model of the lake that would enable various simulations, such as changes in the water level, it is necessary to consider the data that refer to the surrounding terrain (height data, gathered by aerophotogrammetry). The combination of precisely obtained data on heights and depths enables the interpolation for the areas that were not directly included in the survey. The out- put results turned out well, since the lake features mostly low, flattened shores.

Due to unusual output results in the first phase, the comparison of methods of interpolation was repeated for 30233 points within the Lake Vrana Nature Park (Table 4). Of those points, 12851 were depths (bathymetrically measured points), and 17832 were elevations (points with $x, y$ and $z$ values gathered by aero-photogrammetry). Statistic indicators were calculated only for the bathymetrically gathered points. The output results were quite different. The use of elevation points, which are necessary to develop a good digital elevation model of the lake and its surroundings, showed deficiencies in seven statistical parameters (Table 4) and graphic representations of data sets (Fig. 7).

Ordinary cokriging turned out to be the best method of interpolation according to all relevant parameters (Table 4). Figure 7 clearly shows the characteristic of the simple kriging method, when the range of elevation data set in the study 
Table 3. Comparison of manually and automatically determined parameters of the interpolation method (example for OCK).

\begin{tabular}{lrrrrrrrrr}
\hline Model & Range & Sill & Nugget & Lags & Distance & NL $^{*}$ & NS$^{*}$ & SD $^{*}$ & MPE $^{*}$ \\
\hline Spherical (CAD $)$ & 8496.4 & 0.591 & 0.227 & 886.11 & 10633.32 & 12 & 4 & 0.232 & 2.030 \\
Spherical (MD*) & 1777.9 & 0.418 & 0.027 & 150.00 & 1800.00 & 12 & 4 & 0.221 & 2.238 \\
Spherical (CAD*) & 6337.5 & 0.477 & 0.302 & 886.11 & 10633.32 & 12 & 4 & 0.238 & 1.948 \\
Gauss (MD*) & 133.8 & 0.042 & 0.048 & 20.00 & 240.00 & 12 & 4 & 0.220 & 2.235 \\
\hline
\end{tabular}

*IM - interpolation method, NL - number of lags, NS - number of sectors, SD - standard deviation, MPE - maximum prediction error, $\mathrm{CAD}$ - criteria automatically determined, $\mathrm{MD}$ - manually determined.

Table 4. Cross-validation results calculated for elevation data from two data sets, but statistic indicators are only for points gathered by bathymetric measurement.

\begin{tabular}{lrrrrrrrr}
\hline IM & $\begin{array}{r}\text { Number of measured } \\
\text { points }\end{array}$ & $\begin{array}{r}\text { Minimum value } \\
(\mathrm{m})\end{array}$ & $\begin{array}{r}\text { Maximum value } \\
(\mathrm{m})\end{array}$ & $\begin{array}{r}\text { Range } \\
(\mathrm{m})\end{array}$ & $\begin{array}{r}\text { Value sum } \\
(\mathrm{m})\end{array}$ & $\begin{array}{r}\text { Mean value } \\
(\mathrm{m})\end{array}$ & $\begin{array}{r}\text { Variance } \\
\left(\mathrm{m}^{2}\right)\end{array}$ & $\begin{array}{r}\text { Standard deviation } \\
(\mathrm{m})\end{array}$ \\
\hline IDW & 30233 & -1.748 & 4.372 & 6.120 & 1169.497 & 0.091 & 0.199 & 0.446 \\
LP & 30233 & -2.142 & 4.809 & 6.951 & 1793.793 & 0.140 & 0.234 & 1.825 \\
CRS & 30233 & -117.351 & 46.197 & 163.548 & 487.438 & 0.038 & 0.484 \\
SWT & 30233 & -4.134 & 2.881 & 7.016 & 60.581 & 0.005 & 0.107 & 1.351 \\
MQ & 30233 & -1.925 & 2.618 & 4.544 & 360.547 & 0.028 & 0.087 & 0.327 \\
IMQ & 30233 & -87.722 & 40.884 & 128.607 & 464.898 & 0.036 & 1.298 & 0.294 \\
OK & 30233 & -1.700 & 5.551 & 7.250 & 1738.313 & 0.135 & 0.228 & 1.139 \\
SK & 30233 & -1.740 & 2.363 & 4.103 & 186.282 & 0.014 & 0.085 & 0.478 \\
UK & 30233 & -1.662 & 10.137 & 11.799 & 2329.834 & 0.181 & 0.343 & 0.291 \\
DK & 30233 & -5.977 & 4.267 & 10.245 & 1828.414 & 0.142 & 0.562 & 0.586 \\
OCK & 30233 & -1.314 & 2.280 & 3.594 & 543.563 & 0.042 & 0.057 & 0.750 \\
SCK & 30233 & -1.656 & 2.338 & 3.995 & 211.185 & 0.016 & 0.066 & 0.239 \\
UCK & 30233 & -1.665 & 10.136 & 11.802 & 2331.259 & 0.181 & 0.343 & 0.258 \\
DCK & 30233 & -8.972 & 4.976 & 13.949 & 1944.773 & 0.151 & 0.570 & 0.586 \\
\hline
\end{tabular}

area is $307.23 \mathrm{~m}$, in which case the mean value for the entire area is $38.02 \mathrm{~m}$. Along with the ordinary cokriging method, satisfactory results were obtained from the inverse distance weighting method, RBF - multiquadratic and ordinary kriging. The standard deviation according to all three methods was less than $0.5 \mathrm{~m}$.

The differences between the four best methods of interpolation are visible in the two-dimensional (Fig. 10a-d) and three-dimensional graphic representations. Figure $8 \mathrm{a}$ and $\mathrm{b}$ show the more vertically dissected part of the lake, with an $\mathrm{AB}$ profile, and a length of $1500 \mathrm{~m}$, which was used as a further testing sample for the four best interpolation methods. The profile line was drawn so as to cover six bathymetrically measured points.

After drawing the profile line, it was necessary to calculate the intersection for the defined profiles based on the regular network generated by the interpolation, i.e. to convert the two-dimensional profiles into 3-D lines which feature $x$, $y$ and $z$ values.

This approach enabled comparison of the profiles, a clear representation of the interpolated lake's bottom and the detection of deviation between the bathymetrically measured points and those approximated by the model. Figure 9 shows a difference in the interpolation method of deterministic (in- verse distance weighting, RBF - multiquadratic) and geostatistical methods (ordinary kriging, ordinary cokriging).

The final result of comparing methods of interpolation using ArcGIS extension Geostatistical Analyst is to obtain a regular spatial network or grid. Usually, the greatest problem is deciding between greater spatial resolution or pixel size (Hengl, 2006). In this case, the software optimized the pixel size at $40 \mathrm{~m}$. The spatial resolution corresponds to $\mathrm{McCul}-$ lagh's (1988) method of determining pixel size. The size was calculated using a grid calculator and the method of point sample analysis (Hengl, 2006). On the basis of 12851 points and an area of $29.865 \mathrm{~km}^{2}$, a spatial resolution of $24.2 \mathrm{~m}$ was generated. This method (McCullagh, 1988) was not chosen due to a disproportionate ratio between the distance of the profiles and the points measured in them. Due to the high density of the sampling within a profile $(10 \mathrm{~m})$, but also due to variability in the elevation of the neighbouring points, a problem known as the "Prussian helmet" occurs (Šiljeg, 2013). The grid was later used as input data for the purpose of developing a three-dimensional representation. In addition, it can be used to develop various maps to show contours, lake terrain, grid models, slope, etc. 


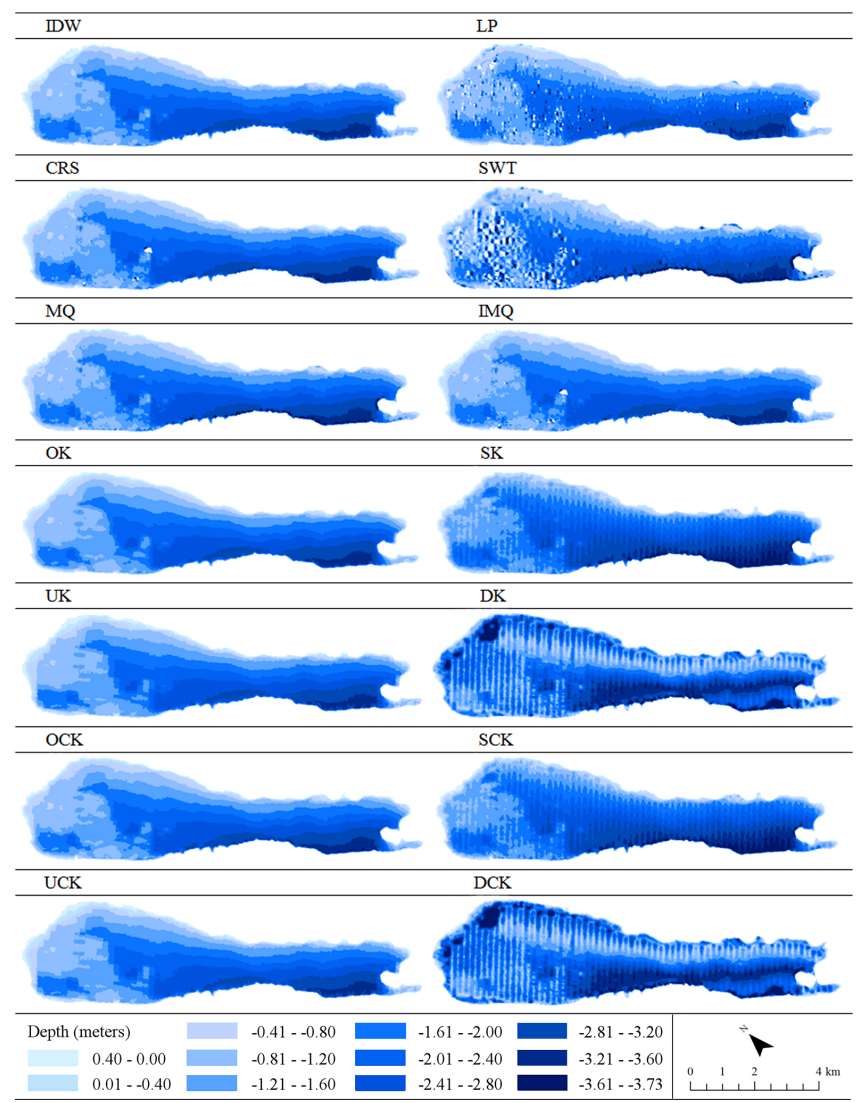

Figure 7. Digital elevation models generated from surveyed data, showing differences between deterministic and geostatistical interpolation methods.
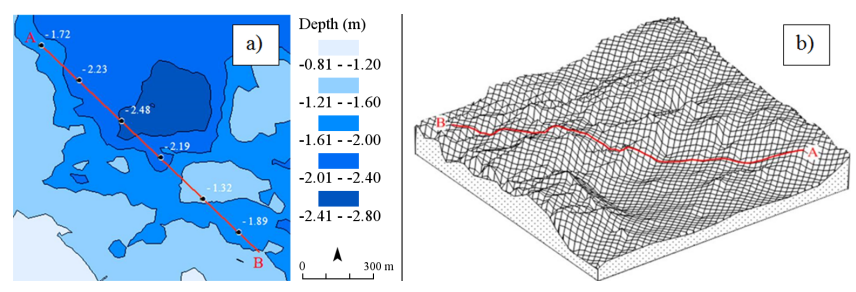

Figure 8. (a) Profile display, contour map. (b) Profile display, threedimensional model.

\subsection{Surface area and volume of the lake}

The final phase of bathymetric research involved calculating the lake's surface area and volume (Diolaiuti et al., 2005; Ahmed, 2010). The output results of a certain analysis depend on the method of data gathering, dissection of the lake bottom of the lake density and distribution of points, spatial resolution (pixel size), algorithms and the interpolation method used.

The volume of a lake can be efficiently calculated by a regular grid obtained by using a certain interpolation method. The calculation process was relatively simple, since the number of pixels was known (18714), as well as the surface

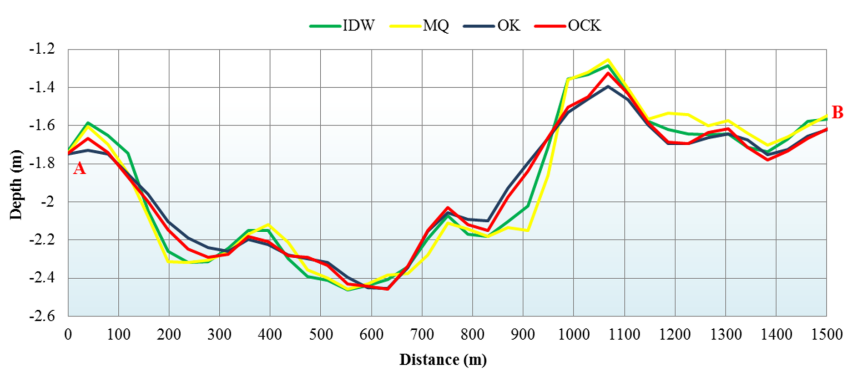

Figure 9. Differences in profile for the four best interpolation methods.
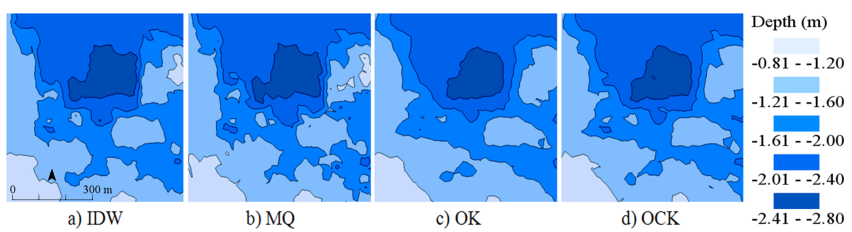

Figure 10. Representation of contours in part of the lake (difference between interpolation methods).

$\left(40 \mathrm{~m} \times 40 \mathrm{~m}=1600 \mathrm{~m}^{2}\right)$ and the height $(z)$ within the coordinate system. A pixel in this case represents a threedimensional object (cube or a quadratic prism) based on which the volume can be calculated.

In order to compare it with other algorithms, the volume was calculated for the regular spatial grid, obtained by the ordinary cokriging interpolation method. The volume amounted to $49783536 \mathrm{~m}^{2}$. This method yielded good results, since the difference between the result and the arithmetic mean for three rules (trapezoidal; Simpson's 3/8) was $293143 \mathrm{~m}^{3}$ (Table 5). The output results of volume calculation depend primarily on the spatial resolution; the lower the resolution, the more precise the calculation, because the leaps in values between pixels become less.

In order to calculate the volume, three more complex Newton-Cotes formulae were used: (1) the extended trapezoidal rule, (2) the extended Simpson's 1/3 rule and (3) the extended Simpson's $3 / 8$ rule (Press et al., 1988). NewtonCotes formulae are very useful and provide a direct technique for approximately calculating an integral by numerical methods and algorithms (their use results in various degrees of errors in the final calculation) (Medved et al., 2010). They are used to calculate the surface area and volume of various shapes. Simpson's rule approximates an integral by the Lagrange polynomial which passes through three points, while the trapezoidal rule approximates by the Lagrange polynomial passing through two points (Palata, 2003).

Table 5 shows calculated values for the volume derived from Newton-Cotes formulae, applied to five different methods of interpolation. Since every method displays a certain level of error in the approximation of the volume, arithmetical means for the three methods were also calculated. 
Table 5. Volume, surface and perimeter of Lake Vrana at $0.4 \mathrm{~m}$ water level in reference to the Prosika gauge.

\begin{tabular}{lrrrrrr}
\hline Water level $(0.4 \mathrm{~m})$ & \multicolumn{7}{c}{ Interpolation method } \\
\cline { 2 - 7 } & IDW & MQ & OK & OCK & NaN & TIN \\
\hline Trapezoid rule $\left(\mathrm{m}^{3}\right)$ & 49512560 & 50839235 & 48904436 & 50077481 & 50007961 & 50108329 \\
Simpson's rule $\left(\mathrm{m}^{3}\right)$ & 49523461 & 50822602 & 48902952 & 50070506 & 50008506 & 50107823 \\
Simpson's $\left.3 / 8{\mathrm{rule}\left(\mathrm{m}^{3}\right)}^{3}\right)$ & 49516428 & 50821012 & 48906375 & 50082051 & 50011883 & 50105204 \\
Arithmetic mean $\left(\mathrm{m}^{3}\right)$ & 49517483 & 50827616 & 48904587 & 50076679 & 50009450 & 50107119 \\
Surface $\left(\mathrm{km}^{2}\right)$ & 29.521 & 30.009 & 29.493 & 29.865 & 29.897 & 29.857 \\
Perimeter $(\mathrm{km})$ & 36.619 & 36.703 & 34.290 & 35.851 & 35.918 & 36.118 \\
\hline
\end{tabular}

The border of the lake for all the models was an isobath at $0.4 \mathrm{~m}$, obtained by interpolating bathymetrically measured depth data and terrain elevation data obtained by aerophotogrammetry. The isobath was converted into a polygon, which was used to determine a raster model within the borders of the polygon. Results of the measurements of surface, perimeter and volume of the lake, regardless of the formula used, greatly depend on the model developed by interpolation (Table 5).

The surface area of Lake Vrana, in relation to its water level (which annually oscillates by $1.93 \mathrm{~m}$ ) varies by almost $4 \mathrm{~km}^{2}$ (Table 6). It can be obtained by manual vectorization based on a geo-referential digital orthophoto $\left(29.412 \mathrm{~km}^{2}\right)$. The process is relatively simple, and the contour of the lake is represented by the border between the water and land, defined by subjective visual approximation. However, $4.6 \%$ of the lake's surface area is covered in dense vegetation (Phragmitetalia), which makes determining the surface area a more complex task. Considering the limitations of the aforementioned method, the research employed previously stated interpolation methods for determining the lake's surface area.

The total surface area of the lake is $30.815 \mathrm{~km}^{2}$, calculated based on the $0.93 \mathrm{~m}$ isobath (mean water level in the observed period from 1947 to 2008) obtained by interpolating data on an elevation of the surrounding terrain and depth of the lake. The interpolation method provided good results in relation to the subsequent testing of the model, because most of the lake's shore is flattened featuring mild slopes and almost no anomalies in data values obtained by bathymetric survey and aero-photogrammetry. The method was also tested by field work, using a precise GPS. The device was used to record information on the most distant borders of the lake at six randomly chosen locations. Since the interpolated border of the lake was transferred into GPS, it was easy to determine the deviation.

The average width of the lake is $2201.4 \mathrm{~m}$ (minimum 262.26 and maximum $3469.31 \mathrm{~m}$ ). The average length of the longitudinal profiles is $8765.43 \mathrm{~m}$ (minimum 1843.55 and maximum $13245.34 \mathrm{~m}$ ). These values were obtained by analysing 68 transverse (northeast-southwest) and 17 longitudinal (southeast-northwest) profiles at $200 \mathrm{~m}$ intervals (at the water level of $0.4 \mathrm{~m}$ ).

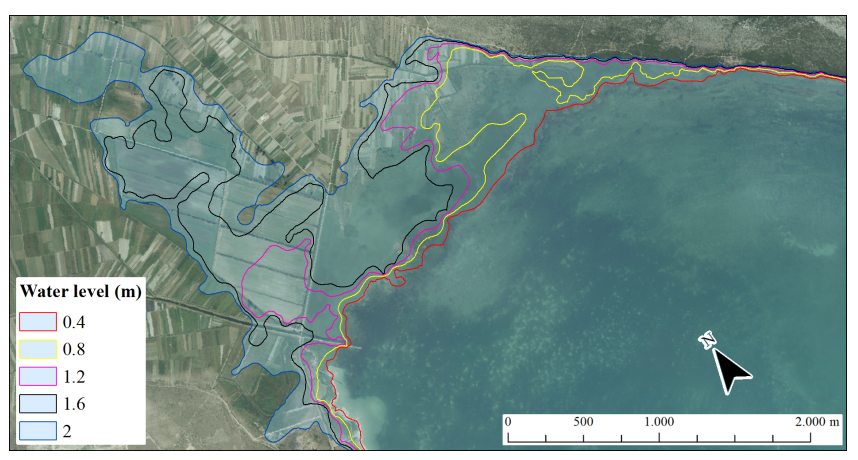

Figure 11. Annual water level oscillation in the northern part of Lake Vrana Nature Park (probable scenario in case the Jasen water pump stops working).

\section{Discussion and conclusion}

The last phase of digital terrain modelling refers to the application of a model (Weibel and Heller, 1991; Hutchinson and Gallant, 2000; Hengl et al., 2003; Oksanen, 2006), therefore this research visualized the annual water level oscillation. A scenario was made for the northwestern Jasen inundation area, outside the Nature Park (Fig. 11). A section of the flooded habitats and cadastre plots within the Nature Park were also determined (Table 7), at a water level of $2 \mathrm{~m}$ (Fig. 12).

The water level map at $2 \mathrm{~m}$ was overlaid with the map of habitats for Lake Vrana Nature Park to the scale of 1:5000. The map was made in accordance with the rules of National Croatian Habitat Classification and comprises 30 classes of habitats (Jelaska, 2010). A sudden change in the water level can change the ecological features of a particular habitat, affecting the flora and fauna of Lake Vrana Nature Park. The analysis concluded that almost half the habitats are endangered if the water level rises to $2 \mathrm{~m}$. The highest level of threat $(100 \%)$ relates to Illyrian-sub-Mediterranean river valley meadows and the lowest level $(1 \%)$ relates to brambles. It is worth noting that $52.7 \%$ of the endangered areas are consolidated arable lands with monoculture crops (cereals), while $18.3 \%$ (37.8 ha) are complex mosaics of crops. 
Table 6. Perimeter and surface area of Lake Vrana at various water levels, for the most suitable (OCK) interpolation method.

\begin{tabular}{lrrr}
\hline Water level (in reference to the Prosika gauge) & Perimeter $(\mathrm{km})$ & Surface area $\left(\mathrm{km}^{2}\right)$ \\
\hline Maximum* & 2.36 & 38.541 & 33.064 \\
Mean & 0.93 & 38.338 & 30.815 \\
Minimum & 0.15 & 34.974 & 29.177 \\
\hline
\end{tabular}

* Within Lake Vrana Nature Park.

Table 7. Percentage of flooded habitats at the water level of $2 \mathrm{~m}$ in reference to the Prosika gauge.

\begin{tabular}{lrrr}
\hline NKS_DESCRIPTION & $\begin{array}{r}\text { Flooded area } \\
\text { (ha) }\end{array}$ & $\begin{array}{r}\text { Total area of the } \\
\text { habitat in the NP (ha) }\end{array}$ & $\begin{array}{r}\text { Percentage } \\
(\%)\end{array}$ \\
\hline Complex mosaic of crops & 37.8 & 206.3 & 18.3 \\
Illyrian-sub-Mediterranean river valley meadows/ & 32.6 & 34.9 & 93.4 \\
Mediterranean halophytic Juncus species & & & \\
Mixed evergreen forests and holm oak maquis & 15.6 & 696.3 & 2.2 \\
Brambles & 6.6 & 685.9 & 1.0 \\
Shore uncovered or rarely covered by vegetation & 4.4 & 6.3 & 70.9 \\
Illyrian-sub-Mediterranean river valley meadows & 2.6 & 2.6 & 100.0 \\
Tree lines at the edges of cultivated areas & 2.1 & 7.2 & 29.5 \\
Brambles/thermophile flooded underbrush & 1.2 & 3.5 & 34.9 \\
Thermophile flooded underbrush & 0.6 & 1.2 & 50.0 \\
Aleppo pine plantations & 0.6 & 65.6 & 0.9 \\
Tyrrhenian-Adriatic limestone & 0.6 & 1.0 & 60.3 \\
Consolidated arable land with monoculture crops (cereals) & 0.6 & 1.1 & 52.7 \\
Man-made or industrial habitats & 0.5 & 11.2 & 4.6 \\
\hline
\end{tabular}

Most field parcels in the park are used for intensive agricultural purposes. The northern part of the park features horticultural plants with multiannual crop rotations. Plants include mostly hybrid species. Various agrotechnical methods are used in order to produce a better level of crop success, as well as fertilizers and chemical components for plant protection (JUPPVJ, 2010). In the northwestern lake area, there is a mixed culture of olive fields, vineyards, horticulture and some cereal crops (JUPPVJ, 2010). Should the water level rise by $2 \mathrm{~m}$, it would partially or completely threaten $45.94 \%$ of the cadastre plots. In the northern part of the park (a flatter area), flooding would threaten the entire area. In the northwestern part, flooding would mostly threaten areas at a lower elevation. These areas have been more susceptible to flooding in the past, as is evident from the specific shape of the field parcels (especially in the northwestern part). The parcels there are narrow (10 $\mathrm{m}$ on average) and extremely elongated $(150 \mathrm{~m})$. The inclination of these parcels $\left(2-5^{\circ}\right)$ is perpendicular to the lake.

The results of this research show that the output results of the digital terrain modelling and corresponding analyses depend on the data-gathering methods, density of samples, interpolation methods, terrain features (mostly vertical dissection), pixel size and algorithms applied. In the research, 14 methods of interpolation were compared; six deterministic and eight geostatistical. Of the five most common meth- ods for gathering elevation data and comparing interpolation methods, two sets of data were used (depth and elevation). They were obtained by various methods, techniques and procedures: bathymetry and aero-photogrammetry. The conclusion is that there is no universal method of interpolation which shows the best results in both sets of data, since the output results depend on the data-gathering method. For example, an optimal method for developing a DEM of the lake's shore was developed, but it turned out to be inadequate for developing a DEM of the lake's bottom. In addition, regardless of the fact that certain authors point out either deterministic or geostatistical methods as more advantageous, it is important to note that there is no single best interpolation method, since they are all conditioned by spatial and temporal components. This means that the result of the comparison and selection of the best method are in fact provisional and dependent on time and space components, the technology used to gather and process data and the area of research.

The fact that geostatistical methods of interpolation employ mathematical functions and the probability theory was one of the reasons for hypothesizing that geostatistical methods would be better interpolators. This was proven, but the research also showed that the differences between geostatistical and deterministic methods were negligible. The multiquadratic function, as the globally most commonly accepted method, was proven to be the best radial basic function, but 


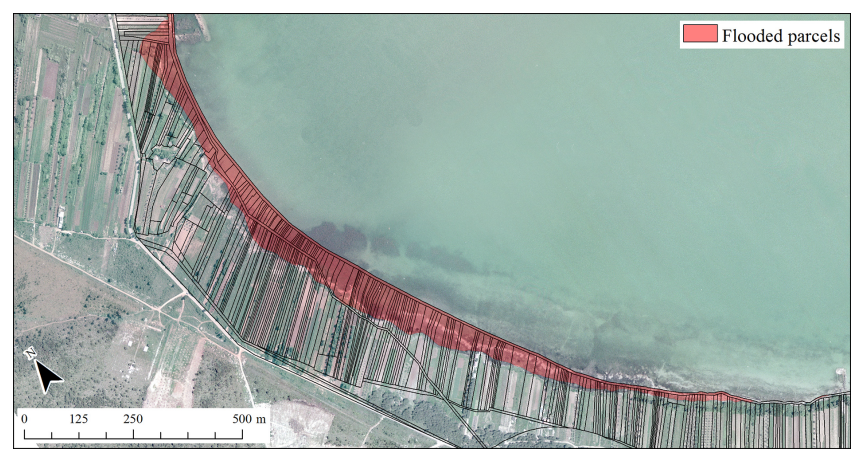

Figure 12. Flooded agricultural parcels in the Pakoštane cadastre at a water level of $2 \mathrm{~m}$ (northwestern section of the park).

also one of the best deterministic interpolation methods in general.

In order to develop a digital model from the bathymetrically gathered data, 14 interpolation methods were compared in two phases. In the first phase (which used 12851 bathymetrically measured points), all the methods compared showed good results, due to the low vertical dissection of the terrain. By using the method of cross-validation and analysing statistical parameters, the conclusion was that the best results were yielded by the simple cokriging method (the standard deviation was $0.197 \mathrm{~m}$ ).

The range of the standard deviation for all 14 methods was between 0.197 and $0.255 \mathrm{~m}$. Due to characteristic issues with output results and the problem of extrapolating data in the first phase, the process of comparing interpolation methods was repeated for the sample of 30233 points within Lake Vrana Nature Park. The output results in the second phase were notably different, and the majority of methods applied showed imperfections. According to all the statistical parameters, the best method of interpolation was ordinary cokriging (Fig. 13). Along with ordinary cokriging, good results were shown by the inverse distance weighting method, RBF - multiquadratic method and ordinary kriging. The standard deviation for all three methods was less than $0.5 \mathrm{~m}$. These methods were compared by graphic representation, calculation and comparison of the profiles, surface area and volume of the lake. The conclusion was that there were no significant differences between the statistical indicators in deterministic or geostatistical methods, whether the parameters were determined automatically or manually. However, by testing the ordinary kriging method, the conclusion was that the reduction in the distance positively affected standard deviation, but negatively affected approximation in the areas that were not included in the direct survey. The interpolated values in those areas turned out to be much greater than the values actually measured at the surrounding points.

Based on the optimal method of interpolation, the lake's surface area, perimeter and volume were calculated at the water level of $0.4 \mathrm{~m}$ in reference to the Prosika gauge.

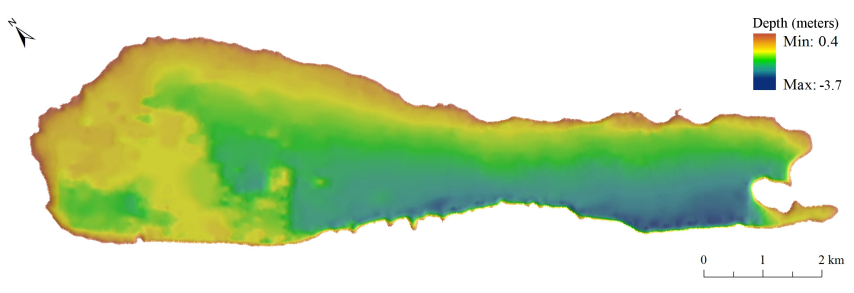

Figure 13. Bathymetric map of Lake Vrana (ordinary cokriging).

The surface area of the lake is $29.865 \mathrm{~km}^{2}$, the perimeter is $35.851 \mathrm{~km}$ and the volume is $50076679 \mathrm{~m}^{3}$. During the bathymetric survey, the conclusion was that a low frequency $(30 \mathrm{kHz})$ could not penetrate the very thick, intertwined "sediment" vegetation which formed the new bottom of the lake. Another problem with low frequency is occasionally significant leaps in profiles, especially in places where the frequency managed to penetrate the vegetation or mud. In order to perform a detailed analysis, a sediment profiler with a frequency of up to $15 \mathrm{kHz}$ should be used to gain detailed information about the layers on the lake's bottom (Lafferty et al., 2005; Pribičević et al., 2007).

All the analyses and conclusions derived can be used for further research on data-gathering methods, interpolation methods, methods of spatial resolution selection and methods of digital terrain analysis. In any future research of Lake Vrana, it would be useful to extend the profiles during the survey, if a single-beam sounder is used, so that the distance between the profiles is no greater than $50 \mathrm{~m}$. In that case the relation between the profiles and the data gathered from the profiles (every $10 \mathrm{~m}$ ) would be much more proportional. In addition, it would be useful to compare the results of the development of the lake's bottom model using singlebeam, multi-beam and laser sounder techniques. It is important to note that the more efficient techniques, such as multibeam ultrasound or laser measurement, might not yield significantly better results due to the morphology of the bottom and the relatively high percentage of dense, native vegetation. The portion of the bottom surveyed would increase in relation to the portion surveyed with the single-beam sounder, but the costs of such research would drastically increase, as well as the amount of data yielded for the processing. In that case, processing stations would have to be employed as well. A frequency of under $15 \mathrm{kHz}$ is recommended for future research, in order to determine the density and volume of sediments. Since $4.6 \%$ of the lake's surface is covered in dense vegetation, it was difficult to determine the exact borders. The dense vegetation prevents sounders from effectively reaching the surface. In order to avoid extrapolation in the bordering areas, the research employed elevation data obtained by aero-photogrammetry and stereo-restitution, where the average distance between the elevation points was $90 \mathrm{~m}$. If future interpolation projects aim for a higher level of precision in the bordering areas, it will be necessary to reduce the 
distance between the elevation points. Recommended methods include aerolaser or aero-photogrammetry. In this case, the distance between the points should be less during stereorestitution (maximum $10 \mathrm{~m}$ ).

The data measured and evaluated enable the development of hydrological and hydro-technical studies which would result in an optimal water level, ensure a biological minimum and economical water minimum, and optimize the water system. In order to determine the volume of the lake, it was necessary to map the lake's bottom, gather data required for the development of the digital elevation model and make a topographic map of the lake's bottom and shoreline relative to its optimal water level, thus creating a sound basis for future activities.

Acknowledgements. We would like to thank anonymous reviewers for valuable comments on the earlier versions of the manuscript, and editor Dominic Mazvimavi who helped to improve the final version.

Edited by: D. Mazvimavi

\section{References}

Aguilar, F. J., Agüera, F., Aguilar, M. A., and Carvajal, F.: Effects of terrain morphology, sampling density, and interpolation methods on grid DEM accuracy, Photoframm. Eng. Rem. S., 71, 805-816, 2005.

Ahmed, S.: Water Volume Calculation of Hill Country Trinity Aquifer Blanco, Hays, and Travis Counties, Central Texas GIS and GPS Applications in Earth Science, available at: http://www.geo.utexas.edu/courses/371C/project/2010F/ Ahmed_Project.pdf (last access: 6 May 2012), 2010.

Bishop, M. P. and Shroder, J. F.: Remote sensing and geomorphometric assessment of topographic complexity and erosion dynamics in the Nanga Parbat massif, in: Tectonics of the Nanga Parbat Syntaxis and the Western Himalaya, edited by: Khan, M. A., Treloar, P. J., Searle, M. P., and Jan, M. Q., Geological Society London, London, 181-199, 2000.

Burrough, P. A. and McDonnell, R. A.: Principles of Geographical Information Systems, Oxford University Press, New York, 1998.

Chaplot, V., Darboux, F., Bourennane, H., Leguédois, S., Silvera, N. and Phachomphon, K.: Accuracy of interpolation techniques for the derivation of digital elevation models in relation to landform types and data density, Geomorphology, 77, 126-141, 2006.

Clarke, J. E. H.: Dynamic Motion Residuals in Swath Sonar Data: Ironing out the Creases, available at: http://www.omg.unb.ca/ omg/papers/Lect_26_paper_ihr03.pdf (last access: 6 May 2012), 2003.

Collins, F. C. and Bolstad, P. V.: A comparison of spatial interpolation techniques in temperature estimation, in: Proceedings of the third International Conference/Workshop on Integrating GIS and Environmental Modeling, Santa Fe, New Mexico, Santa Barbara, 21-25 January 2001, 2001.

Cressie, N.: Statistics for Spatial Data, revised Edn., John Wiley and Sons, New York, 1993.
Dikau, R., Brabb, E. E., Mark, R. K., and Pike, R. J.: Morphometric landform analysis of New Mexico, Zeitschrift für Geomorphologie, N.F. Suppl.-Bd., 101, 109-126, 1995.

Diolaiuti, G., Kirkbride, M. P., Smiraglia, C., Benn, D. I., D’Agata, C. and Nicholson, L.: Calving processes and lake evolution at Miage Glacier (Mont Blanc, Italian Alps), Ann. Glaciol., 40, 207-214, 2005.

DGU, Digitalna ortofoto karta - listovi šireg područja PP Vransko jezero, Državna geodetska uprava, Zagreb, 2012a.

DGU, Hrvatska osnovna karta - listovi šireg područja PP Vransko jezero, Državna geodetska uprava, Zagreb, 2012b.

Erdogan, S.: A comparison of interpolation methods for producing digital elevation models at the field scale, Earth Surf. Proc. Land., 34, 366-376, 2009.

Ernstsen, V., Noormets, R., Hebbeln, D., Bartholomé, A., and Flemming, B.: Precision of high-resolution multibeam echo sounding coupled with high-accuracy positioning in a shallow water coastal environment, Geo-Mar. Lett., 26, 141-149, 2006.

Fabulić, M.: Softver za filtriranje podatka o dubinama, Geodetski ured Teodolit, Zadar, 2012.

Finkl, C. W., Benedet, L., and Andrews, J. L.: Laser airborne depth sounder (lads): a new bathymetric survey technique in the service of coastal engineering, environmental studies, and coastal zone management, in: Proceedings of the 17th annual national conference on beach preservation technology, Tallahassee, Florida, 11-13 February 2004, 11-26, 2004.

Fisher, P. F. and Tate, N. J.: Causes and consequences of error in digital elevation models, Prog. Phys. Geog., 30, 467-489, 2006.

Guarneri, J. C. and Weih Jr., R. C.: Comparing Methods for Interpolation to Improve Raster Digital Elevation Models, Journal of the Arkansas Academy of Science, 66, 77-81, 2012.

Hartkamp, A. D., De Beurs, K., Stein, A., and White, J. W.: Interpolation Techniques for Climate Variables, NRG-GIS Series 99-0, CIMMYT, Mexico, D. F, 1999.

Hengl, T.: Finding the right pixel size, Computer and Geosciences, 32, 1283-1298, 2006.

Hengl, T., Gruber, S., and Shrestha, D. P.: Digital terrain analysis in ILWIS: lecture notes and user guide, International Institute for Geo-information Science and Earth Observation (ITC), Enschede, the Netherlands, 2003.

Heritage, G. L., Milan, D. J., Large, A. R. G., and Fuller, I. C.: Influence of survey strategy and interpolation model on DEM quality, Geomorphology, 112, 334-344, 2009.

Hofierka, J., Cebecauer, T., and Š́ri, M.: Optimisation of Interpolation Parameters Using a Cross-validation, in: Digital Terrain Modelling, edited by: Peckham, R. J. and Jordan, G., Development and Applications in a Policy Support Environment, Series: Lecture Notes in Geoinformation and Cartography, SpringerVerlag, Berlin, Heidelberg, 67-82, 2007.

Hu, K., Li, B., Lu, Y., and Zhang, F.: Comparison of various spatial interpolation methods for non-stationary regional soil mercury content, Environ. Sci., 25, 132-137, 2004.

Hutchinson, M. F. and Gallant, J. C.: Digital elevation models and representation of terrain shape, in: Terrain Analysis: Principles and Applications, edited by: Wilson, J. P and Gallant, J. C., John Wiley and Sons, New York, 29-50, 2000.

IHO: Manual of Hydrography, Publication M-13, 1st Edn., International Hidrographic Bureau, Monaco, 2005. 
Jelaska, S.: Karta staništa PP Vransko jezero u mjerilu 1:5000, Park prirode Vransko jezero, Biograd, 2010.

JUPPVJ: Plan upravljanja Parkom prirode Vransko jezero, PHARE 2005: Institucionalno jačanje i provedba ekološke mreže NATURA 2000 u Hrvatskoj (ed. Wolfgang, S.), Biograd, 2010.

Kuspilić, N.: Hidrotehničke građevine; Građevine na vodotocima, Građevinski fakultet, Sveučilište u Zagrebu, Zagreb, 2008.

Lafferty, B., Quinn, R., and Breen, C.: A side-scan sonar and highresolution Chirp sub-bottom profile study of the natural and anthropogenic sedimen tary record of Lower Lough Erne, northwestern Ireland, J. Archaeol. Sci., 33, 756-766, 2005.

Li, J. and Heap, A. D.: A Review of Spatial Interpolation Methods for Environmental Scientists, Geoscience Australia, Record 2008/23, Canberra, 2008.

Li, Z., Zhu, Q., and Gold, C.: Digital Terrain Modeling, CRC Press, London, 2005.

Malvić, T.: Primjena geostatistike u analizi geoloških podataka, Udžbenici Sveučilišta u Zagrebu, INA-Industrija nafte d.d., Zagreb, 2008.

McCullagh, M. J.: Terrain and surface modelling systems: theory and practice, Fotogrammetric Record, 12, 747-779, 1988.

Medved, I., Pribičević, B., Medak, D., and Kuzmanić, I.: Usporedba metoda interpolacije batimetrijskih mjerenja za praćenje promjena volumena jezera, Geod. List, 68, 71-86, 2010.

Millaresis, G. C. and Argialas, D. P.: Extraction and delineation of alluvial fansfrom digital elevation models and Landsat Thematic Mapper images, Photoframm. Eng. Rem. S., 66, $1093-$ 1101, 2000.

Naoum, S. and Tsanis, I. K.: Ranking spatial interpolation techniques using a GIS-based DSS, Global Nest J., 6, 1-20, 2004.

NOAA: Hydrographic Manual, 4th Edn., National Oceanic and Atmospheric Administration, US Department of Commerce, Rockville, 1976.

Oksanen, J.: Digital Elevation model Error in Terrain Analysis, PhD Thesis, Faculty of Science, University of Helsinki, Helsinki, 51 pp., 2006.

Ožanić, N.: Hidrotehničke regulacije, Građevinski fakultet, Zavod za hidrotehniku i geotehniku, Sveučilište u Rijeci, Rijeka, 2002.

Palata, D.: Newton-Cotesove formule numeričke integracije, available at: https://www.google.hr/search?client=opera\&q=palata+ Newton+Cotesove+formule $\&$ sourceid $=$ opera $\& i e=U T F-8 \& o e=$ UTF-8\&gfe_rd=cr\&ei=tjrLVePGKcaG8QeSiK0Y (last access: 2 October 2012), 2003.

Press, W. H., Teukolsky, S. A., Vetterling, W. T., and Flannery, B. P.: Numerical Recipes in C, The Art of Scientific Computing, Cambridge University Press, New York, 1988.

Pribičević, B., Medak, D., and Kordić, B.: Primjena dvofrekventne batimetrije u određivanju sedrenih naslaga, Geod. List, 1, 1-18, 2007.
Romić, D., Romić, M., Borošić, J., and Poljak, M.: Mulching decreases nitrate leaching in bell pepper (Capsicum annuum L.) cultivation, Agr. Water Manage., 60, 87-97, 2003.

Shary, P. A, Sharaya, L. S., and Mitusov, A. V.: Fundamental quantitative methods of land surface analysis, Geoderma, 107, 1-32, 2002.

Šikić, Z., Pernar, N., Yerkovich, B. B., and Rogošić, J.: Influence of water levels of Vrana Lake and the Adriatic Sea to the water chemistry of Vrana lake, Acta Adriat., 54, 199-212. 2013

Šiljeg, A.: Digitalni model reljefa u analizi geomorfometrijskih parametara - primjer PP Vransko jezero, Doktorski rad, PMF, Sveučilište u Zagrebu, 187 pp., 2013.

Smith, S. L, Holland, D. A., and Longley, P. A.: Interpreting Interpolation: The Pattern of Interpolation Errors in Digital Surface Models Derived from Laser Scanning Data, CASA Working Paper 66, Centre for Advanced Spatial Analysis, University College London, London, 2003.

Tan, Q. and Xu, X.: Comparative Analysis of Spatial Interpolation Methods: an Experimental Study, Sensors \& Transducers, 165, 155-163, 2014.

Tucker, G. E., Catani, F., Rinaldo, A., and Bras, R. L.: Statistical analysis of drainage density from digital terrain data, Geomorphology, 36, 187-202, 2001.

Večernji list: http://www.vecernji.hr/dalmacija (last access: 8 June 2012, 2012.

Webster, R. and Oliver, M. A.: Geostatistics for Environmental Scientists, 2nd Edn., John Wiley \& Sons Ltd, Chichester, 2007.

Weibel, R. and Heller, M.: Digital terrain modelling, in: Geographical Information Systems: Principles and Applications, Vol. 1, Principles, edited by: Maguire, D. J., Goodchild, M. F., and Rhind, D., Longman, Harlow, 1991.

Weng, Q.: An evaluation of spatial interpolation accuracy of elevation data, in: Progress in Spatial Data Handling, edited by: Riedl, A., Kainz, W., and Elmes, G. A., Springer-Verlag, Berlin, 805824, 2006.

Wilson, J.: Digital terrain modeling, Geomorphology, 137, 269297, 2011.

Wilson, J. P. and Gallant, J. C.: Digital terrain analysis, in: Terrain analysis: principles and applications, edited by: Wilson, J. P. and Gallant, J. C., John Wiley and Sons, New York, 1-27, 2000.

Yang, X. and Hodler, T.: Visual and statistical comparisons of surface modeling techniques for point-based environmental data, Cartography and Geographic Information Science, 27, 165-175, 2000.

Zhou, F., Guo, H. C., Ho, Y.-S., and Wu, C. Z.: Scientometric analysis of geostatistics using multivariate methods, Scientometrics, 73, 265-279, 2007. 